\title{
Conjugal inflammatory bowel disease: a systematic review and European survey
}

\section{Maria Pia Costa-Santos ${ }^{a}$, Catarina Frias-Gomes ${ }^{a}$, António Oliveiraa, João Sabinob, Miriam Mañosac, Pierre Ellul' ${ }^{d}$ Ana Sampaio ${ }^{e}$, Luisa Avedano', Salvo Leonef, Jean-Frédéric Colombelg, Joana Torres ${ }^{a}$}

Hospital Beatriz Ângelo, Loures, Portugal; University Hospital of Leuven, Leuven, Belgium; Hospital Universitari Germans Trias i Pujol, Badalona, Spain; Mater Dei Hospital, Malta; Portuguese Association of Inflammatory Bowel Disease; European Federation of Crohn's \& Ulcerative Colitis Associations; Icahn School of Medicine at Mount Sinai, New York City, NY, USA

\section{Abstract}

${ }^{a}$ Division of Gastroenterology, Hospital Beatriz Ângelo, Loures, Portugal (Maria Pia Costa-Santos, Catarina Frias-Gomes, António Oliveira, Joana Torres); ${ }^{b}$ Division of Gastroenterology, University Hospital of Leuven, Leuven, Belgium (João Sabino); 'Division of Gastroenterology, Hospital Universitari Germans Trias i Pujol, Badalona, Spain (Miriam Mañosa); ${ }^{\mathrm{d} D i v i s i o n}$ of Gastroenterology, Mater Dei Hospital, Malta (Pierre

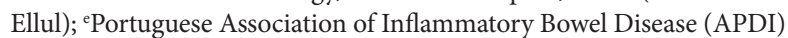
(Ana Sampaio); ${ }^{\mathrm{f}}$ European Federation of Crohn's \& Ulcerative Colitis Associations (EFCCA) (Luisa Avedano, Salvo Leone); ${ }^{\mathrm{g} D i v i s i o n}$ of Gastroenterology, Icahn School of Medicine at Mount Sinai, New York City, NY, USA (Jean-Frédéric Colombel)

Conflict of Interest: None

Correspondence to: Joana Torres, Division of Gastroenterology, Hospital Beatriz Ângelo, Loures, Portugal, Avenida Carlos Teixeira, 3 - 2674-514 Loures, Portugal, e-mail: joanatorres00@gmail.com

Received 29 July 2020; accepted 6 December 2020; published online 26 February 2021

DOI: https://doi.org/10.20524/aog.2021.0598

\section{Introduction}

Inflammatory bowel disease (IBD) results from a complex relationship between genetic susceptibility, environmental factors and intestinal microbiota, resulting in a selfperpetuating abnormal mucosal immune response [1]. A positive family history of IBD is the strongest risk factor for developing it [2]. Advances in genetics have led to the identification of more than 240 independent loci associated with IBD [3-6]. However, together these loci only explain $13.1 \%$ and $8.2 \%$ of the variance in disease predisposition for Crohn's disease (CD) and ulcerative colitis (UC), respectively, and therefore do not fully explain disease susceptibility or causality [4]. This difference in risk might therefore be explained by shared environmental exposures, thought to have a crucial role in disease pathogenesis.

Scattered reports of IBD in couples appeared in the literature in the early $70 \mathrm{~s}$. These were later followed by 
a population-based study showing that the frequency of IBD after marriage to an individual with this disease is significantly increased relative to what would be expected by chance alone, given the population size studied [7]. Moreover, the offspring of couples where both parents are affected by IBD have a very high risk of developing disease. However, despite the apparently very high risk for the progeny and the unusual existence of couples with IBD, very few studies exist. Since the first studies were conducted, no further research has been carried out in this area. Therefore, our aim was to further characterize conjugal IBD. We started by conducting a systematic review of all studies and case reports involving couples with IBD. Simultaneously, we conducted a Europeanwide survey with the goal of identifying a cohort of conjugal IBD cases, describing their phenotypic features, and evaluating the risk for progeny in a modern cohort.

\section{Materials and methods}

\section{Systematic review}

PubMed was searched for all articles published until February 2020, using the keywords: inflammatory bowel disease, Crohn's disease, ulcerative colitis, spouses, couples and marriage or married. Studies not written in English, those not reporting on couples, and review articles were excluded. Data were collected on the timing of IBD diagnosis in the couple in relation to one another, and the presence of IBD in their children. Based on the diagnosis and cohabitation dates, we could assess which member of the couple was diagnosed first, evaluate the onset of disease relative to cohabitation, and stratify patients into 3 groups: a) group A, when both members of the couple were diagnosed prior to cohabitation; b) group $B$, when one member was diagnosed before and another after cohabitation; c) group $\mathrm{C}$, when both members were diagnosed after cohabitation [8].

\section{Cross-sectional survey}

We further conducted a cross-sectional survey with the aim of identifying couples where both members were affected by IBD, describing their disease type, phenotype and circumstances of their diagnosis (before or after cohabitation with their partners). We also aimed to identify the children from couples both affected by IBD to estimate the risk for the progeny to develop disease.

For this purpose, an electronic survey was created using REDCap [9,10] (made available by the Portuguese Society of Gastroenterology, through its platform for multicenter studies - CEREGA) and translated into 7 languages (English, Spanish, French, Italian, German, Dutch and Portuguese) by healthcare professionals. The survey was approved by the Portuguese Data Protection Committee. The questionnaires were advertised and distributed from July 2018 to December
2019, by the European Crohn's and Colitis Organization (ECCO) in their newsletter, by the European Federation of Crohn's \& Ulcerative Colitis Associations (EFCCA) through their journal and social media platforms, and by some national patients' associations (Portuguese, Italian, Spanish, Dutch, and Flanders). The survey language and questions were set up in such a way that it could be answered either by doctors or patients. The person filling in the questionnaire answered the questions for all family members with IBD (couples and their offspring).

\section{Data collection}

Demographic data of both members of the couple and their offspring, degree of consanguinity, disease type, diagnosis date, phenotypic features, family history of IBD, personal and family history of other immune-mediated disease (IMID), smoking habits, current and previous treatments and surgery were collected through our electronic survey. For couples, we also retrieved information about their cohabitation, namely the date when the they started living together and whether the IBD diagnosis was made before or after cohabitation. Based on the diagnosis and cohabitation dates, we categorized couples into 3 groups, in a similar way to that used for the systematic review and described above. For those couples with children, we also asked about the total number of children, whether they were biological children, the mode of delivery, breast-feeding and exposure to antibiotics in childhood.

\section{Statistical analysis}

Data from the systematic review were qualitatively reviewed and described using descriptive statistics. All continuous variables were represented as mean and standard deviation or median and range, while categorical variables were expressed as frequency and proportions. Whenever there was missing data, the denominator was adjusted and proportions calculated to reflect only the reported data. Differences in mean continuous variables with a normal distribution were analysed using an independent Student's $t$-test and one-way analysis of variance (ANOVA). The other continuous variables were compared using the Wilcoxon Mann-Whitney test and Kruskal-Wallis test. To explore univariate associations in the distribution of categorical data, the $\chi^{2}$ test or Fisher's exact test was used, as appropriate. A P-value $<0.05$ was considered statistically significant. To estimate the risk of IBD for progeny, a survival curve was created using a Kaplan-Meier analysis. Survival analysis was performed including all the progeny from couples with IBD and also excluding the progeny of couples that self-reported as being homosexual. Statistical analysis was performed using the software Statistical Package for Social Sciences (SPSS) (version 23.0). 


\section{Results}

\section{Systematic review}

Details of the literature search, article screening and retrieval are summarized in Supplementary Fig. 1. We identified 25 studies that reported on couples with IBD, of which 20 were included in the systematic review: 1 populationbased study [7], 1 case series [8], and 18 case reports (Table 1).

Overall, 68 couples with IBD had been described in the literature, of which 45 (66\%) were concordant regarding disease type: 37 with CD and 8 with UC. In 7 (10.3\%) couples both spouses were diagnosed before marriage (group A); in 16 (23.5\%) IBD developed in the second spouse after marriage to an individual with disease (group B) after an average of $3 \pm 1$ years of cohabitation; and in 45 (66.2\%) IBD was diagnosed in both members after co-habitation (group C), with the second affected spouse being diagnosed $6.1 \pm 6.1$ years after the first. In group B, the first spouse to develop IBD had CD in 11 of 16 pairs, whereas the second spouse developed CD in 10 pairs. In group C, the first spouse diagnosed with IBD had CD in 30 of 45 pairs and the second developed CD in 33 couples.

Overall, there were 102 children reported from these couples (although the information was missing in 10 case reports), and 30 were eventually diagnosed with IBD (overall prevalence of 29\%): 26 with CD and 4 with UC. In the study by Bennet et al, which included 19 couples with IBD (mostly of Jewish ancestry), the disease developed in the offspring in 36\% of cases [8]. Laharie et al calculated the cumulative probability for the offspring to develop IBD to be $3 \%$ by age of 10 years, $22 \%$ by 20 years and of $33 \%$ by age 28 [7]. The age of diagnosis of IBD in the offspring, when reported, ranged from 4-35 years. All the affected children born from parents concordant for CD developed CD themselves $(n=21)$.

\section{Cross-sectional survey}

A total of 534 entries in the survey were registered. Within those, we identified 58 couples where both members of the couple had IBD. Patients' demographic, clinical characteristics and IBD phenotypic features are described in Tables 2 and 3. The survey was answered by one of the elements of the couple in $81 \%(46 / 57)$ of cases. Couples born in 11 and living in 9 different countries were represented. The country of birth and residence of both members of the couple was Italy in $46 \%$ $(26 / 57)$ and $45 \%(25 / 55)$, respectively, and Portugal in $19 \%$ $(11 / 57)$ and $20 \%(11 / 55)$, respectively (Supplementary Table 1$)$. In 47 (81\%) couples both members were Caucasian. In 3 couples both spouses were Jewish and in 2 couples one member was Jewish. There was consanguinity in 1 couple. Twenty couples self-reported as being homosexual (14 female couples).

\section{IBD in couples}

Thirty-six (62\%) couples were concordant for IBD: 17 with CD and 19 with UC. There was concordance for disease

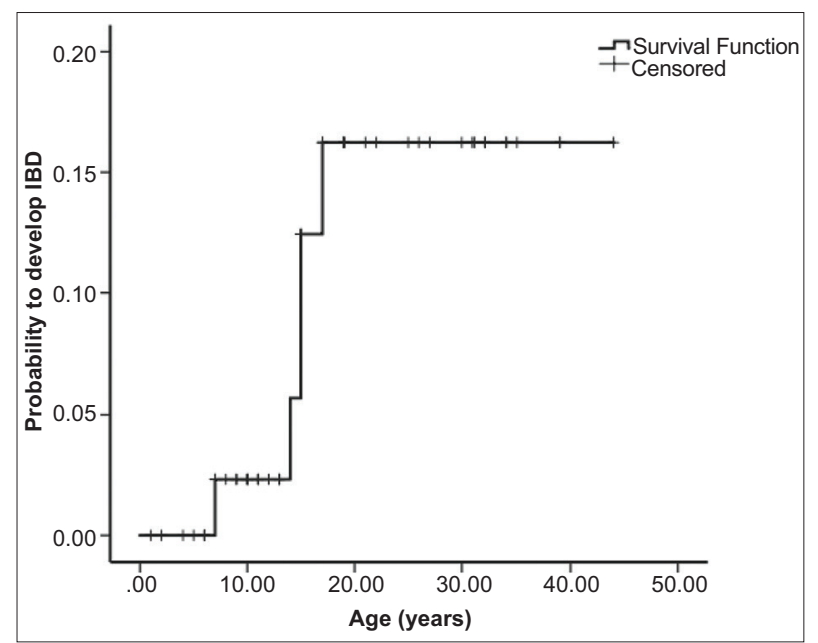

Figure 1 Cumulative probability of developing inflammatory bowel disease in children born from heterosexual couples with disease (Kaplan-Meier analysis)

location in 5 couples with CD (4 had ileal disease and 1 had colonic disease) and in 12 pairs with UC ( 2 had proctitis, 2 left-sided colitis, and 8 extensive colitis). Regarding smoking habits, $41 \%(23 / 56)$ pairs were current or previous smokers and $39 \%(22 / 56)$ had never smoked.

In total, 42 of the $116(36 \%)$ spouses had at least one other IMID (7 patients had 2 or more IMID) and 66 (57\%) had a family history of IMID. A family history of IBD in first-degree relatives (FDRs) was present in 25 patients (22\%; 7 patients had 2 FDRs with IBD) and in second-degree relatives (SDRs) in 23 (20\%) (1 patient had both FDRs and SDRs).

Seventeen (29.3\%) couples were concordant for previous or current treatment with biologics, in 20 (34.5\%) couples neither spouse had ever been medicated with biologics, and the remaining 21 were discordant regarding this therapy.

Within 56 couples, 24 (42.9\%) were included in group A, 7 (12.5\%) in group B and 25 (44.6\%) in group C; 2 couples were not assigned to any group because of missing data (Table 4). In group $\mathrm{B}$, the disease appeared in the second spouse an average of $7.2 \pm 8.9$ years after cohabitation. The first spouse to develop IBD had CD in 2 of 7 pairs, whereas the second spouse developed CD in 3 of 7 pairs. In group $C$, the first affected spouse developed IBD an average of $8.3 \pm 7.9$ years after cohabitation and the second $3.9 \pm 4.3$ years after the first. The first spouse to develop IBD had CD in 7 of 22 pairs; the second member developed CD in 11 couples (data missing for 3 couples).

\section{IBD in the offspring}

In total, 35 couples had 65 children. The demographic and clinical characteristics of children with IBD are described in Supplementary Table 2. Overall, 6 (9\%) children developed IBD, $3 \mathrm{UC}, 2 \mathrm{CD}$, and 1 indeterminate colitis (IC), at a mean age of 13.6 \pm 3.8 (range 7-17) years. Regarding the affected children, in 2 cases their parents both had IBD at the time of conception, in 
4 M.P. Costa-Santos et al

Table 1 Description of studies included in the systematic review

\begin{tabular}{|c|c|c|c|c|c|c|c|c|c|}
\hline $\begin{array}{l}\text { Author, Year } \\
\text { [Ref] }\end{array}$ & Country & $\begin{array}{l}\text { No. of } \\
\text { couples }\end{array}$ & $\begin{array}{l}\text { Concordance } \\
\text { for IBD }\end{array}$ & Group A & Group B & Group C & $\begin{array}{l}\text { No. of } \\
\text { children }\end{array}$ & $\begin{array}{l}\text { No. } \\
\text { children } \\
\text { with IBD }\end{array}$ & Notes \\
\hline $\begin{array}{l}\text { Rosenberg, } \\
1976 \text { [13] }\end{array}$ & USA & 1 & CD-UC & & & $\begin{array}{l}1^{\text {st }} \text { spouse } \\
\text { in the year } \\
\text { of the first } \\
\text { pregnancy } \\
2^{\text {nd }} \text { spouse } \\
9 \text { years after } \\
\text { the } 1^{\text {st }}\end{array}$ & 1 & $\begin{array}{l}1 \text { (UC) } \\
\text { Diagnosed } \\
\text { at age of } \\
7,7 \text { years } \\
\text { after the } \\
1^{\text {st }} \text { spouse } \\
\text { and } \\
2 \text { years } \\
\text { before the } \\
2^{\text {nd }} \text { spouse }\end{array}$ & \\
\hline $\begin{array}{l}\text { Whorwell, } \\
1978 \text { [14] }\end{array}$ & UK & 1 & CD-CD & & & $\begin{array}{l}1^{\text {st }} \text { spouse } \\
31 \text { years/ } \\
2^{\text {nd }} \text { spouse } \\
35 \text { years } \\
\text { after CoHab }\end{array}$ & NR & & \\
\hline $\begin{array}{l}\text { Zetzel, } \\
1978 \text { [15] }\end{array}$ & USA & 1 & CD-CD & & & $\begin{array}{l}1^{\text {st }} \text { spouse } \\
23 \text { years/ } \\
2^{\text {nd }} \text { spouse } \\
32 \text { years } \\
\text { after CoHab }\end{array}$ & 2 & $\begin{array}{l}1(\mathrm{CD}) \\
\text { Diagnosed } \\
\text { at age of } \\
32,2 \text { years } \\
\text { after the } \\
2^{\text {nd }} \text { spouse }\end{array}$ & \\
\hline $\begin{array}{l}\text { Whorwell, } \\
1981 \text { [16] }\end{array}$ & UK & 1 & CD-CD & & $\begin{array}{l}2^{\text {nd }} \text { spouse } \\
3 \text { years } \\
\text { after } \\
\mathrm{CoHab}\end{array}$ & & NR & & \\
\hline $\begin{array}{l}\text { Kirsner, } 1982 \\
\text { [17] }\end{array}$ & USA & 1 & CD-UC & & & $\begin{array}{l}\text { Timing of } \\
\text { diagnoses } \\
\text { not } \\
\text { reported, } \\
\text { but both } \\
\text { developed } \\
\text { IBD after } \\
\text { CoHab }\end{array}$ & NR & & \\
\hline $\begin{array}{l}\text { Hershfield, } \\
1984 \text { [18] }\end{array}$ & Canada & 1 & CD-CD & & & $\begin{array}{l}1^{\text {st }} \text { spouse } \\
3 \text { years after } \\
\text { the first } \\
\text { pregnancy } \\
2^{\text {nd }} \text { spouse } \\
1 \text { years after } \\
\text { the } 1^{\text {st }}\end{array}$ & 1 & $\begin{array}{l}1(\mathrm{CD}) \\
\text { Diagnosed } \\
\text { at age of } 4, \\
6 \text { months } \\
\text { after the } \\
2^{\text {nd }} \text { spouse }\end{array}$ & \\
\hline $\begin{array}{l}\text { Rhodes, } \\
1985 \text { [19] }\end{array}$ & UK & 2 & $\mathrm{CD}-\mathrm{CD}: 2$ & & & $\begin{array}{l}\text { Couple 1: } \\
1^{\text {st }} \text { spouse } \\
8 \text { years/ } \\
2^{\text {nd }} \text { spouse } \\
10 \text { years } \\
\text { after } \\
\text { CoHab; } \\
\text { Couple } 2 \text { : } \\
1^{\text {st }} \text { spouse } \\
8 \text { years } / 2^{\text {nd }} \\
\text { spouse } 26 \\
\text { years after } \\
\text { CoHab }\end{array}$ & NR & & \\
\hline
\end{tabular}

(Contd...) 
Table 1 (Continued)

\begin{tabular}{|c|c|c|c|c|c|c|c|c|c|}
\hline $\begin{array}{l}\text { Author, Year } \\
\text { [Ref] }\end{array}$ & Country & $\begin{array}{l}\text { No. of } \\
\text { couples }\end{array}$ & $\begin{array}{l}\text { Concordance } \\
\text { for IBD }\end{array}$ & Group A & Group B & Group C & $\begin{array}{l}\text { No. of } \\
\text { children }\end{array}$ & $\begin{array}{l}\text { No. } \\
\text { children } \\
\text { with IBD }\end{array}$ & Notes \\
\hline $\begin{array}{l}\text { Holmes, } \\
1986[20]\end{array}$ & UK & 1 & $\mathrm{CD}-\mathrm{CD}$ & & & $\begin{array}{l}1^{\text {st }} \text { spouse } \\
6 \text { years } / 2^{\text {nd }} \\
\text { spouse } 11 \\
\text { years after } \\
\text { CoHab }\end{array}$ & NR & & \\
\hline $\begin{array}{l}\text { Purrman, } \\
1987[21]\end{array}$ & Germany & 1 & CD-CD & & $\begin{array}{l}2^{\text {nd }} \text { spouse } \\
2 \text { years } \\
\text { after } \\
\text { CoHab }\end{array}$ & & NR & & \\
\hline $\begin{array}{l}\text { Murray, } \\
1988 \text { [22] }\end{array}$ & Canada & 1 & CD-CD & & & $\begin{array}{l}\text { Both } \\
\text { spouses } \\
\text { developed } \\
\text { IBD in the } \\
\text { same year } \\
\text { (4 years } \\
\text { after } \\
\text { the first } \\
\text { pregnancy) }\end{array}$ & 2 & NR & \\
\hline $\begin{array}{l}\text { Dua, } 1988 \\
{[23]}\end{array}$ & Scotland & 1 & CD-CD & & & $\begin{array}{l}2^{\text {nd }} \text { spouse } 1 \\
\text { years after } \\
\text { the } 1^{\text {st }}\end{array}$ & 1 & $\begin{array}{l}1(\mathrm{CD}) \\
\text { Diagnosed } \\
\text { at age } 11 \\
\text { years }\end{array}$ & \\
\hline $\begin{array}{l}\text { Lobo, } \\
1988[24]\end{array}$ & UK & 1 & CD-CD & & & $\begin{array}{l}1^{\text {st }} \text { spouse } \\
37 \text { years } / 2^{\text {nd }} \\
\text { spouse } 39 \\
\text { years after } \\
\text { CoHab }\end{array}$ & NR & & \\
\hline $\begin{array}{l}\text { Darchis, } \\
1989 \text { [25] }\end{array}$ & France & 1 & CD-CD & & & $\begin{array}{l}1^{\text {st }} \text { spouse } \\
17 \text { years } / 2^{\text {nd }} \\
\text { spouse } 31 \\
\text { years after } \\
\text { CoHab }\end{array}$ & 4 & $\begin{array}{l}4(\mathrm{CD}) \\
1 \text { child } \\
\text { diagnosed } \\
\text { at age of } \\
9 \text { (before } \\
\text { parents), } \\
1 \text { at age of } \\
16 \text { (at the } \\
\text { same time } \\
\text { of the } 1^{\text {st }} \\
\text { spouse), } \\
2 \text { at age of } \\
14 \text { and } 17 \\
\text { (7 years } \\
\text { and } 11 \\
\text { years after } \\
\text { the } 1^{\text {st }} \\
\text { spouse) }\end{array}$ & \\
\hline $\begin{array}{l}\text { Bennet, } \\
1991[8]\end{array}$ & USA & 19 & $\begin{array}{l}\text { CD-UC: } 11 \\
\text { (57\%) } \\
\text { CD-CD:6 } \\
\text { (32\%) } \\
\text { UC-UC: } 2 \\
(11 \%)\end{array}$ & $5(26 \%)$ & $\begin{array}{l}7(37 \%) \\
2^{\text {nd }} \text { spouse } \\
6.4 \text { years } \\
\text { after } \\
\text { CoHab }\end{array}$ & $\begin{array}{l}7(37 \%) \\
1^{\text {st }} \text { spouse } \\
11.9 \text { years } \\
\text { after } \\
\text { CoHab; } \\
2^{\text {nd }} \text { spouse } \\
6.8 \text { years } \\
\text { after the } 1^{\text {st }}\end{array}$ & 33 & $\begin{array}{l}12,36 \% \\
\text { (CD: } 9 ; \\
\text { UC: } 3 \text { ) } \\
\text { Age of } \\
\text { diagnosis } \\
\text { ranged } \\
\text { from } 7-35 \\
\text { years }\end{array}$ & $\begin{array}{l}33(87 \%) \\
\text { of Jewish } \\
\text { ethnicity }\end{array}$ \\
\hline
\end{tabular}

(Contd...) 
Table 1 (Continued)

\begin{tabular}{|c|c|c|c|c|c|c|c|c|c|}
\hline $\begin{array}{l}\text { Author, Year } \\
\text { [Ref] }\end{array}$ & Country & $\begin{array}{l}\text { No. of } \\
\text { couples }\end{array}$ & $\begin{array}{l}\text { Concordance } \\
\text { for IBD }\end{array}$ & Group A & Group B & Group C & $\begin{array}{l}\text { No. of } \\
\text { children }\end{array}$ & $\begin{array}{l}\text { No. } \\
\text { children } \\
\text { with IBD }\end{array}$ & Notes \\
\hline $\begin{array}{l}\text { Batty, } \\
1994 \text { [26] }\end{array}$ & UK & 1 & UC-UC & & & $\begin{array}{l}1^{\text {st }} \text { spouse } 9 \\
\text { years/ } 2^{\text {nd }} \\
\text { spouse } 28 \\
\text { years after } \\
\text { CoHab }\end{array}$ & 2 & NR & \\
\hline $\begin{array}{l}\text { Singh, } 1995 \\
\text { [27] }\end{array}$ & UK & 1 & CD-CD & & & $\begin{array}{l}1^{\text {st }} \text { spouse } \\
1 \text { years/ } 2 \\
\text { nd spouse } 5 \\
\text { years after } \\
\text { CoHab }\end{array}$ & NR & & \\
\hline $\begin{array}{l}\text { Laharie, } \\
2001[7]\end{array}$ & $\begin{array}{l}\text { France } \\
\text { and } \\
\text { Belgium }\end{array}$ & 30 & $\begin{array}{l}\text { CD-UC: } 10 \\
\text { (33\%) } \\
\text { CD-CD: } 17 \\
\text { (57\%) } \\
\text { UC-UC: } 3 \\
(10 \%)\end{array}$ & $2(7 \%)$ & $\begin{array}{l}6(20 \%) \\
2^{\text {nd }} \text { spouse } \\
1.5 \text { years } \\
\text { after } \\
\text { CoHab }\end{array}$ & $\begin{array}{l}22(73 \%) \\
1^{\text {st }} \text { spouse: } 9 \\
\text { years after } \\
\text { CoHab; } \\
2^{\text {nd }} \text { spouse } \\
8.5 \text { years } \\
\text { after the } 1^{\text {st }}\end{array}$ & 54 & $\begin{array}{l}9,17 \% \\
(\mathrm{CD}) \\
\text { Age of } \\
\text { diagnosis } \\
\text { ranged } \\
\text { from } 14- \\
18 \text { years }\end{array}$ & $\begin{array}{l}\text { Population- } \\
\text { based }\end{array}$ \\
\hline $\begin{array}{l}\text { Sood, } 2001 \\
{[28]}\end{array}$ & India & 1 & UC-UC & & & $\begin{array}{l}1^{\text {st }} \text { spouse } \\
26 \text { years/ } 2 \\
\text { nd spouse } 27 \\
\text { years after } \\
\text { CoHab }\end{array}$ & NR & & \\
\hline $\begin{array}{l}\text { Méndez- } \\
\text { Sánchez, } \\
2009 \text { [29] }\end{array}$ & Mexico & 1 & UC-UC & & $\begin{array}{l}2^{\text {nd }} \text { spouse } \\
4 \text { years } \\
\text { after } \\
\text { CoHab }\end{array}$ & & NR & & \\
\hline $\begin{array}{l}\text { Triantafillidis, } \\
2014 \text { [30] }\end{array}$ & Greece & 1 & CD-CD & & & $\begin{array}{l}\text { Both } \\
\text { spouses } \\
\text { developed } \\
\text { IBD } 13 \\
\text { years after } \\
\text { Cohab (12 } \\
\text { and } 20 \\
\text { months } \\
\text { after } \\
\text { divorce) }\end{array}$ & 2 & $\begin{array}{l}1(\mathrm{CD}) \\
\text { Diagnosed } \\
\text { at age } \\
\text { of } 20,5 \\
\text { years after } \\
\text { divorce }\end{array}$ & \\
\hline
\end{tabular}

aymptoms started 4 years before cohabitation

$C D$, Crohn's disease; CoHab, cohabitation; IBD, inflammatory bowel disease; NR, not reported; UC, ulcerative colitis

2 cases only 1 parent had IBD prior to conception and in 1 case both parents developed IBD after the child's birth (data missing from 1 couple). All parents were diagnosed with IBD before their children, except in 1 case where 1 parent was diagnosed before and the other at the same time. In total, 7 parents had UC, $4 \mathrm{CD}$, and 1 IC. Parents of children with UC both had UC in 2 cases; children with CD were born from couples where 1 spouse had CD. None of the affected offspring belonged to the same family. Three children were first-borns and 3 the second child. Among the 65 children, 14 were born from 10 homosexual couples: one was the offspring who developed IC and none of them was assigned as non-biologic child in the survey. The overall prevalence of IBD in the progeny of all couples was $9 \%$ (6/65); when considering only the heterosexual couples this prevalence was $10 \%(5 / 51)$. The cumulative probability of developing IBD in children born from couples where both members had disease was $2 \%$ by
10 years of age, $5 \%$ at 14 years, $10 \%$ at 15 years, and $13 \%$ at 20 years. After excluding children born from homosexual couples, the probability of IBD was $2 \%$ at 10 years, $12 \%$ at 15 years, and $16 \%$ by 20 years (Fig. 1). Since there were no diagnoses of IBD at ages beyond 20, we could not estimate the cumulative probability for developing IBD beyond this age. An exploratory analysis was performed to identify predictive factors for developing IBD in children and none of those factors was associated with an increased risk for progeny (Supplementary Table 3).

\section{Discussion}

In the present study, we aimed to better characterize conjugal IBD. We started by conducting a systematic review, 
Table 2 Demographic and clinical characteristic of patients included in the web survey $(n=116)$

\begin{tabular}{lc}
\hline Characteristics & Value \\
\hline Age, years, mean \pm SD & $44.6 \pm 13.9$ \\
Female sex, $n(\%)$ & $66(57 \%)$ \\
\hline Race, $n(\%)^{\mathrm{a}}$ & \\
White & $95(86 \%)$ \\
Other & $16(14 \%)$ \\
Ethnicity, $n(\%)^{\mathrm{b}}$ & \\
Jewish & $8(8 \%)$ \\
Non-Jewish & $93(92 \%)$ \\
\hline Family history of IBD, $n(\%)^{\mathrm{d}}$ & \\
FDRs & $25(22 \%)$ \\
SDRs & $23(20 \%)$ \\
Personal history of other IMID, $n(\%)$ & $42(36 \%)$ \\
Family history of other IMID, $n(\%)$ & $66(57 \%)$ \\
\hline Smoking status, $n(\%)^{\mathrm{c}}$ & \\
Never smoker & $57(50 \%)$ \\
Ever smoker & $57(50 \%)$ \\
\hline
\end{tabular}

Missing data from: ${ }^{\mathrm{a} 5}$ patients, ${ }^{\mathrm{b}} 15$ patients, ${ }^{\mathrm{c}} 2$ patients; ${ }^{\mathrm{d}}$ One patient had both FDRs and SDRs

FDRs, first-degree relatives; IBD, inflammatory bowel disease; IMID, immunemediated disease; SD, standard deviation; SDRs, second-degree relatives

Table 3 Phenotypic characteristics of patients included in the web survey $(\mathrm{n}=116)$

\begin{tabular}{lcc}
\hline Characteristics & $\mathrm{CD}(\mathrm{n}=54)$ & $\begin{array}{c}\mathrm{UC} \text { and } \\
\mathrm{IC}(\mathrm{n}=62)\end{array}$ \\
\hline $\begin{array}{l}\text { Age of diagnosis - years, } \\
\text { mean } \pm \text { SD }\end{array}$ & $27.6 \pm 9.0$ & $31.1 \pm 11.4$ \\
$\begin{array}{l}\text { Disease location, } n(\%)^{\mathrm{a}} \\
\text { L1/L2/L3 }\end{array}$ & $26(62 \%) / 8$ & $\mathrm{~N} / \mathrm{A}$ \\
& $\mathrm{N} / \mathrm{A}$ & $10(19 \%) / 18$ \\
E1/E2/E3 & & $(34 \%) / 25(47 \%)$ \\
& $22(41 \%)$ & 0 \\
Perianal disease, $n(\%)$ & & \\
$\begin{array}{l}\text { Current or previous } \\
\text { therapies, } n \text { (\%) }\end{array}$ & $29(54 \%)$ & $54(87 \%)$ \\
5-ASA & $24(44 \%)$ & $40(65 \%)$ \\
Steroids & $14(26 \%)$ & $14(23 \%)$ \\
Thiopurines & $31(57 \%)$ & $23(37 \%)$ \\
Biologics & $30(56 \%)$ & $9(15 \%)$ \\
Previous surgeries, $n(\%)$ &
\end{tabular}

${ }^{\mathrm{a} A c c o r d i n g}$ to Montreal Classification; Missing data from: ${ }^{\mathrm{b}} 12$ patients, c9 patients

$C D$, Crohn's disease; IC, indeterminate colitis; $N / A$, not applicable; $S D$, standard deviation; UC, ulcerative colitis; 5-ASA, 5-aminosalicylates

complemented by a cross-sectional survey. Overall, 68 couples with IBD were identified in our systematic review, the majority being concordant as regards disease type. The overall prevalence of IBD in the offspring was $29 \%$. The literature was composed mainly of case reports with 1 or 2 couples, which included only a scanty description of data regarding couples with IBD and their offspring, as besides disease diagnosis, no other information was provided. Only 2 studies had a larger sample size $[7,8]$. The first one, published in 1991 by Bennet et al, identified 19 couples with IBD, with $87 \%$ of patients being Jewish [8]. Later, Laharie et al reported on a population-based study from Northern France that included 30 couples with IBD; in 22 instances the disease developed after marriage in both partners and this was greater than expected by chance $(\mathrm{P}<0.02)$ [7].

Acknowledging the paucity and poor quality of data in the literature, mostly based on case reports, we decided to develop a web-based survey. This allowed us to identify 58 couples across Europe where both members were affected with IBD. In line with what we had observed in the systematic review, almost two thirds of couples were concordant for IBD.

The systematic review and the survey showed that in $90 \%$ and $57 \%$ of couples, respectively, one or both members were diagnosed after cohabitation (groups B and C). Although we cannot rule out the possibility that higher disease awareness could have led to the IBD diagnosis in the unaffected spouses, it seems unlikely, as the diagnosis of IBD was established in the second spouse 7.2 years after cohabitation in group B and 3.9 years after the first member in group $C$. This suggests that the same environment must be shared for several years before IBD develops. It is plausible that specific microbiota shared between couples could predispose to the disease. We did observe a very high rate of IBD and IMID in the personal history and family history, perhaps indicating a genetic predisposition. Our survey did not intend to capture childhood exposures in the couples, as a high recall bias could be expected.

The concordance for CD in conjugal forms (groups B and C) in the systematic review (52\%) was higher than in the survey (22\%). These numbers arise mostly from the study of Northern France and could be related to the higher prevalence of CD in that region. The concordance for $\mathrm{CD}$ in conjugal forms in Bennet's study (21\%) [8] and in our survey were similar. Thus, there seems to be no apparent trend towards concordance for any type of IBD in conjugal forms.

In the systematic review and in the survey the first spouse to develop IBD had CD in $67 \%$ and $31 \%$ of conjugal forms, and the second in $70 \%$ and $48 \%$, respectively. Therefore, it seems that the risk for developing CD or UC in the second spouse is similar, as described by Laharie et al [7]. In about one third of couples, both spouses had already been or were being treated with biologics, reflecting modern IBD management.

The prevalence of IBD in the offspring was around $29 \%$ in the systematic review. In the study by Bennet et al the diagnosis of IBD was established in 12 of 33 (36\%) children from these couples. Laharie et al reported a prevalence of IBD of $17 \%$ among the 54 children born from 25 couples; the risk for progeny when both parents were affected was estimated to be as high as 33\% by the age of 28. However, these studies were conducted in highrisk populations for developing IBD (Jewish ethnicity and in a high-incidence area for disease), which may have led to an 
Table 4 Characterization of couples based on timing of diagnosis and cohabitation $(n=56)$

\begin{tabular}{lccc}
\hline Characteristics & Group A & Group B & Group C \\
\hline Inclusion criteria & $\begin{array}{l}\text { Both spouses diagnosed } \\
\text { before Cohab }\end{array}$ & $\begin{array}{l}\text { One spouse diagnosed before } \\
\text { and one after Cohab }\end{array}$ & $\begin{array}{l}\text { Both spouses diagnosed after } \\
\text { Cohab }\end{array}$ \\
Couples, $n(\%)^{\mathrm{a}}$ & $24(42.9 \%)$ & $7(12.5 \%)$ & $25(44.6 \%)$ \\
\hline $\begin{array}{l}\text { Age of diagnosis - years, mean } \pm S D \\
\text { First spouse }\end{array}$ & $22.5 \pm 3.9$ & $21.3 \pm 3.8$ & $33.8 \pm 9.9$ \\
$\quad$ Second spouse & $24.4 \pm 5.2$ & $31.5 \pm 9.1$ & $37.6 \pm 7.9$ \\
Concordance for IBD, $n$ & 10 & 1 & 6 \\
CD & 6 & 2 & 9 \\
UC & & & 6 \\
aTwo couples were not assigned to any group because of missing data & & \\
CoHab, cohabitation; $C D$, Crohn's disease; $S D$, standard deviation; UC, ulcerative colitis & &
\end{tabular}

overestimation of the risk for the progeny. In our survey, the prevalence of IBD in the progeny was $9 \%$ in all couples, and $10 \%$ after excluding homosexual couples. The cumulative probability of developing disease in children of heterosexual couples reached at most $16 \%$ by age of 20 , much higher than when only one single parent is affected (predictive risk up to $2 \%$ for a 10 year period) [11], but still lower than originally estimated in this high-risk population. However, these numbers could still be an underestimation, since 20 children were aged 10 years or less ( 1 already diagnosed with IBD) at the time of the survey. In the systemic review, $87 \%$ of children were diagnosed with CD, suggesting a trend toward CD in offspring especially when both parents have $\mathrm{CD}$, as previously described $[7,8]$. In our survey, a difference of 15.8 years was found between the mean age at diagnosis of parents and their children. These results are in line with the study by Cabré et al, who found that the youngest members in pairs from different generations in the same family were diagnosed at an earlier age than the oldest ones (43.5 vs. 21.2, $\mathrm{P}<0.0005)$ [12]; this finding can be only associated with a higher awareness for symptoms of IBD leading to an earlier diagnosis in younger generations.

None of the environmental factors studied in the offspring (Supplementary Table 3) was associated with an increased risk of IBD for progeny, although the numbers are too small to draw any definitive conclusions.

Our study had some strengths and limitations. This represents the first survey of couples with IBD, supported by a systematic review on the same topic, providing the features of diagnosis of spouses with IBD and their offspring in a total of 126 couples. Most of studies published in the literature are single case reports. Only 1 population-based study was available and represented the largest study, with a total of 30 couples [7]. Our study and survey increased the sample size of conjugal forms of IBD in a population from 11 different countries, provided more detail on the phenotypic characteristics of their disease, and assessed for the first time the presence of personal and family history of IMID. This study also offers a more accurate and reassuring estimate of the risk for progeny to prospective parents with IBD, which may help in preconception counseling and family planning.
Regarding the limitations, in the survey most of the questionnaires were answered by patients, who may provide unreliable data, namely as regards the phenotypic features and previous treatments. Overall, 34\% of couples self-reported as being homosexual, which was unexpected. The reason for the apparent high prevalence of homosexual couples in our survey is unknown, but this could certainly introduce bias in the risk for progeny. To estimate more accurately the probability of IBD in offspring we excluded these couples' offspring from the analysis. Overall, there were few cases of IBD in children, partially related to the age of the progeny, limiting the assessment of a pattern connecting parents and children and the analysis of predictive factors for developing IBD. Finally, our data were not population-based and we were therefore unable to calculate whether the risk of developing disease in the second member of a couple was higher than by chance, as was previously done [7]. For the same reason, we did not have a control group with a single parent affected, as the estimates of IBD in the progeny of IBD parents have been already well detailed in population-based studies [11].

In summary, our study provides a more updated description of IBD in couples and an estimation of risk in the offspring of couples with disease, lower than previously reported. Nevertheless, the unaffected children from couples with IBD constitute a group at very high risk for developing disease that could be enrolled in future studies looking at disease prediction and prevention. Identification of these high-risk families now offers the possibility of planning further studies to better investigate disease pathogenesis and the earlier stages of IBD.

\section{Acknowledgments}

This study was supported by the Portuguese Society of Gastroenterology, through its platform for multicenter studies, CEREGA (Centro Nacional de Registo de Dados em Gastrenterologia); We would like to thank to national patients' associations [Associação Portuguesa de Doença Inflamatória do Intestino (APDI), Associazione per le malattie infiammatorie 
croniche dell'intestino (AMICI), Crohn en colitis ulcerosa vereniging vZw (CCV-VZW) and Crohn en colitis ulcerosa vereniging Nederland (CCUVN)], European Federation of Crohn's \& Ulcerative Colitis Associations (EFCCA) and European Crohn's and Colitis Organization (ECCO) for advertising and distributing the survey. We would also like to thank the healthcare professionals who translated the survey.

\section{Summary Box}

\section{What is already known:}

- The frequency of inflammatory bowel disease (IBD) after marriage to an individual with the disease is greater than what would be expected by chance alone

- Offspring of couples where both parents are affected by IBD have a very high risk of developing disease

\section{What the new findings are:}

- IBD in couples occurs mostly after marriage to an individual with disease

- About two thirds of couples are concordant as regards IBD type

- The risk of IBD in the offspring of couples where both spouses are affected by the disease is higher than when only one parent is affected, but lower than previously reported

\section{References}

1. Knights D, Silverberg MS, Weersma RK, et al. Complex host genetics influence the microbiome in inflammatory bowel disease. Genome Med 2014;6:107.

2. Santos MPC, Gomes C, Torres J. Familial and ethnic risk in inflammatory bowel disease. Ann Gastroenterol 2018;31:14-23.

3. Jostins L, Ripke S, Weersma RK, et al; International IBD Genetics Consortium (IIBDGC). Host-microbe interactions have shaped the genetic architecture of inflammatory bowel disease. Nature 2012;491:119-124.

4. Liu JZ, van Sommeren S, Huang H, et al; International IBD Genetics Consortium. Association analyses identify 38 susceptibility loci for inflammatory bowel disease and highlight shared genetic risk across populations. Nat Genet 2015;47:979-986.

5. de Lange KM, Moutsianas L, Lee JC, et al. Genome-wide association study implicates immune activation of multiple integrin genes in inflammatory bowel disease. Nat Genet 2017;49:256-261.

6. Lee H-S, Cleynen I. Molecular profiling of inflammatory bowel disease: is it ready for use in clinical decision-making? Cells 2019;8:535.
7. Laharie D, Debeugny S, Peeters M, et al. Inflammatory bowel disease in spouses and their offspring. Gastroenterology 2001;120:816-819.

8. Bennett RA, Rubin PH, Present DH. Frequency of inflammatory bowel disease in offspring of couples both presenting with inflammatory bowel disease. Gastroenterology 1991;100:1638-1643.

9. Harris PA, Taylor R, Thielke R, Payne J, Gonzalez N, Conde JG. Research electronic data capture (REDCap) - a metadata-driven methodology and workflow process for providing translational research informatics support. J Biomed Inform 2009;42:377-381.

10. Harris PA, Taylor R, Minor BL, et al. The REDCap consortium: Building an international community of software platform partners. J Biomed Inform 2019;95:103208.

11. Moller FT, Andersen V, Wohlfahrt J, Jess T. Familial risk of inflammatory bowel disease: a population-based cohort study 1977-2011. Am J Gastroenterol 2015;110:564-571.

12. Cabré E, Mañosa M, García-Sánchez V, et al; ENEIDA Project of the Spanish Working Group in Crohn's Disease and Ulcerative Colitis (GETECCU). Phenotypic concordance in familial inflammatory bowel disease (IBD). Results of a nationwide IBD Spanish database. J Crohns Colitis 2014;8:654-661.

13. Rosenberg JL, Kraft SC, Kirsner JB. Inflammatory bowel disease in all three members of one family. Gastroenterology 1976;70:759-760.

14. Whorwell PJ, Eade OE, Hossenbocus A, Bamforth J. Crohn's disease in a husband and wife. Lancet 1978;2:186-187.

15. Zetzel L. Crohn's disease in a husband and wife. Lancet 1978;2:583.

16. Whorwell PJ, Hodges JR, Bamforth J, Wright R. Crohn's disease in husband and wife. Lancet 1981;1:334.

17. Kirsner JB. Later development of inflammatory bowel disease in the healthy spouse of a patient. N Engl J Med 1982;307:1148.

18. Hershfield NB. Crohn's disease in a mother, father and son. Can Med Assoc J 1984;131:1190, 1193.

19. Rhodes JM, Marshall T, Hamer JD, Allan RN. Crohn's disease in two married couples. Gut 1985;26:1086-1087.

20. Holmes GK, Painter NS. Crohn's disease in married couples. Gut 1986;27:350.

21. Purrmann J, Cleveland S, Miller B, Strohmeyer G. Crohn's disease in a married couple. Hepatogastroenterology 1987;34:132-133.

22. Murray CJ, Thomson AB. Marital idiopathic inflammatory bowel disease. Crohn's disease in a husband and wife. J Clin Gastroenterol 1988;10:95-97.

23. Dua KS, Mowat NA. Familial Crohn's disease, including spouse. Scott Med J 1988;33:372-373.

24. Lobo AJ, Foster PN, Sobala GM, Axon AT. Crohn's disease in married couples. Lancet 1988;1:704-705.

25. Darchis I, Colombel JF, Cortot A, Devred M, Paris JC. Crohn's disease in a married couple and their four children. Lancet 1989;1:737.

26. Batty GM, Wilkins WE, Morris JS. Ulcerative colitis in a husband and wife. Gut 1994;35:562-563.

27. Singh K, Saunders JH, Foley RJ. Inflammatory bowel disease in married couples. Gut 1995;37:158.

28. Sood A, Midha V, Sood N. Ulcerative colitis in a married couple. Indian J Gastroenterol 2001;20:38.

29. Méndez-Sánchez N, Pichardo-Bahena R, Uribe Esquivel M. Ulcerative colitis in husband and wife. First report in Mexico. Rev Gastroenterol Mex 2009;74:246-248.

30. Triantafillidis JK, Spyropoulos C, Rentis A, Vagianos K. Development of Crohn's disease in husband and wife: the role of major psychological stress. Ann Gastroenterol 2014;27:433-434. 


\section{Supplementary material}

Supplementary Table 1 Country of birth and residence of couples included in the web survey $(\mathrm{n}=58)$

\begin{tabular}{lcc}
\hline Country & $\begin{array}{c}\text { Country of birth } \\
\mathrm{n}(\%)\end{array}$ & $\begin{array}{c}\text { Country of } \\
\text { residence }^{\mathrm{b}} \mathrm{n}(\%)\end{array}$ \\
\hline Italy & 26 & 25 \\
Portugal & 11 & 11 \\
\hline Spain & 7 & 7 \\
Netherlands & 3 & 3 \\
\hline Belgium & 2 & 3 \\
\hline Ireland & 2 & 2 \\
\hline Australia & 1 & 1 \\
Malta & 2 & 2 \\
\hline Belgium-Romania & 1 & 0 \\
Portugal-Angola & 1 & 0 \\
\hline Portugal-Brazil & 1 & 0 \\
\hline France & 0 & 1 \\
\hline
\end{tabular}

Missing data from: ${ }^{\mathrm{a} 1}$ couple, ${ }^{\mathrm{b}} 3$ couples

Supplementary Table 2 Demographic and clinical characteristics of children included in the web survey

\begin{tabular}{lllllcllll}
\hline Children & Sex & IBD & $\begin{array}{l}\text { IBD in } \\
\text { parents }\end{array}$ & $\begin{array}{l}\text { Other IMID } \\
\text { in parents }\end{array}$ & $\begin{array}{c}\text { Age of } \\
\text { diagnosis }\end{array}$ & $\begin{array}{l}\text { Smoking } \\
\text { habits }\end{array}$ & $\begin{array}{l}\text { Delivery } \\
\text { mode }\end{array}$ & $\begin{array}{c}\text { Breast-feeding } \\
\text { Exposure to } \\
\text { antibiotics }\end{array}$ \\
\hline Child 1 & Female & CD & CD-UC & Yes & 15 & Never & C-section & No & No \\
Child 2 & Female & CD & CD-IC & No & 15 & Never & Vaginal & $6-12 \mathrm{M}$ & Yes \\
$\begin{array}{l}\text { Child } 3 \\
\text { Children }\end{array}$ & Female & UC & UC-UC & Yes-No & 7 & Never & Vaginal & No & Yes \\
Child 4 & Female & UC & UC-UC & No & 14 & Never & Vaginal & $6-12 \mathrm{M}$ & Yes \\
Child 5 & Female & UC & CD-UC & No & 17 & Never & Vaginal & $6-12 \mathrm{M}$ & Yes \\
Child 6 & Missing & IC & CD-UC & No & Missing & Ever & Missing & Missing & Missing \\
\hline
\end{tabular}

CD, Crohn's disease; IBD, inflammatory bowel disease; IC, indeterminate colitis; IMID, immune-mediated disease; $M$, months; UC, ulcerative colitis

Supplementary Table 3 Predictive factors for developing inflammatory bowel disease in children $(\mathrm{n}=65)$

\begin{tabular}{lccc}
\hline Factors & Children with IBD $(\mathrm{n}=6)$ & Children without IBD $(\mathrm{n}=59)$ & P-value \\
\hline Delivery mode, $n(\%)$ & $4(80 \%)$ & $40(71 \%)$ & 0.999 \\
$\quad$ Vaginal & $1(20 \%)$ & $16(29 \%)$ & 0.307 \\
C-section & $3(60 \%)$ & $46(79 \%)$ & 0.999 \\
Breast-feeding, $n(\%)^{\mathrm{b}}$ & $4(80 \%)$ & $40(69 \%)$ & 0.692 \\
Exposure to antibiotics, $n(\%)^{\mathrm{b}}$ & & & 0.999 \\
Other IMID in parents, $n(\%)$ & $2(33 \%)$ & $26(44 \%)$ & $8(14 \%)$ \\
$\quad$ One or both parents & $1(17 \%)$ & & \\
\multicolumn{1}{l}{ Both parents }
\end{tabular}

IBD, inflammatory bowel disease; IMID, immune-mediated disease. Missing data from: ${ }^{a} 4$ children, ${ }^{\mathrm{b}} 2$ children 


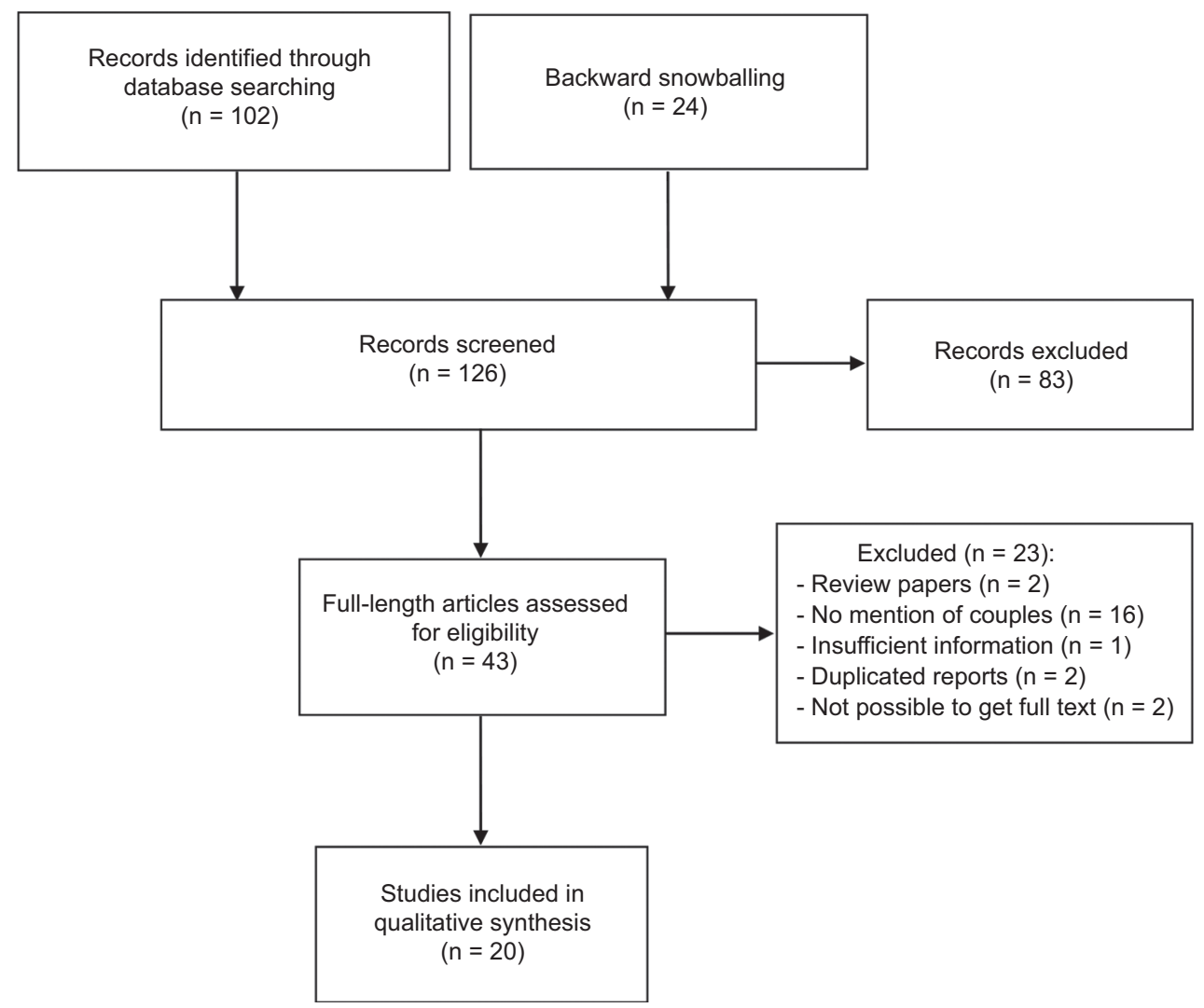

Supplementary Figure 1 PRISMA diagram detailing the literature search 